\title{
PENINGKATAN PELAKSANAAN KESELAMATAN PASIEN DALAM PELAYANAN KESEHATAN DI RUMAH SAKIT
}

\author{
Erta Iman Jelita Harefa/181101138
}

ertahrf08@gmail.com

\begin{abstract}
Abstrak
Latar belakang: Keselamatan pasien (patient safety) merupakan prioritas dalam aspek pelayanan di rumah sakit dan sudah menjadi tuntutan kebutuhan dalam pelayanan kesehatan. Untuk itu diperlukan gerakan keselamatan pasien di rumah sakit agar menghindari kesalahan pada prinsip dalam pengobatan pasien yang harus dipertanggungjawabkan oleh pimpinan pengobatan.

Tujuan: Penulisan ini bertujuan untuk mengetahui dan memberi informasi tentang peningkatan pelaksanaan keselamatan pasien dalam pelayanan kesehatan di rumah sakit. Metode: Penulisan ini menggunakan metode literature review dengan pendekatan jurnal atau artikel, buku dan $e$-book yang relevan dan akurat serta berfokus pada peningkatan pelaksanaan keselamatan pasien dalam pelayanan kesehatan di rumah sakit dengan menggunakan Google Scholar, Portal Garuda, dan Jurnal Keperawatan Indonesia.

Hasil: Berdasarkan hasil pencarian literatur di dapatkan beberapa standar keselamatan pasien dalam pelayanan kesehatan di rumah sakit yang terdiri dari hak pasien, mendidik pasien dan keluarga, keselamatan pasien dan kesinambungan pelayanan, penggunaan metode-metode peningkatan kinerja, peran kepemimpinan, mendidik staf, dan komunikasi untuk mencapai keselamatan pasien.

Pembahasan: keselamatan pasien adalah hal yang menjadi perhatian bagi rumah sakit dalam memberikan pelayanan kesehatan pada pasien/klien. Dalam keselamatan pasien ini, setiap rumah sakit sudah diwajibkan untuk melakukan gerakan keselamatan pasien sesuai dengan standar departemen kesehatan.

Penutup: Pelaksanaan keselamatan pasien saat ini sudah memiliki peningkatan atau kemajuan yang dapat dilihat dari perbandingan Peraturan Menteri Kesehatan Republik Indonesia No. 1691 Tahun 2011 dengan Peraturan Menteri Kesehatan Republik Indonesia No. 11 Tahun 2017 yang memberikan pembaharuan dengan menyesuaikan perkembangan fasilitas kebutuhan pelayanan.
\end{abstract}

Kata kunci: peningkatan, keselamatan pasien, pelayanan kesehatan 


\section{LATAR BELAKANG}

Keselamatan pasien merupakan prioritas dalam aspek pelayanan di rumah sakit dan sudah menjadi tuntutan kebutuhan dalam pelayanan kesehatan. Keselamatan pasien (patient safety) adalah permasalahan yang sangat penting dalam setiap pelayanan kesehatan sehingga keselamatan merupakan tanggungjawab dari pemberi jasa pelayanan kesehatan terutama pelayanan keperawatan di setiap unit perawatan baik akut maupun kronis harus berfokus pada keselamatan pasien baik dalam tatanan rumah sakit, komunitas maupun perawatan di rumah. Menurut Permenkes RI No. 11 Tahun 2017 tentang keselamatan pasien adalah sistem yang membuat asuhan pasien lebih aman yang meliputi asesmen risiko, identifikasi dan pengelolaan risiko pasien, pelaporan dan analisis insiden, kemampuan belajar dari insiden serta tindakan solusi yang akan diambil untuk meminimalkan timbulnya risiko dan mencegah terjadinya cedera yang disebabkan oleh kesalahan akibat melaksanakan suatu tindakan atau tidak mengambil tindakan yang seharusnya diambil.

Untuk itu keselamatan pasien menjadi hal yang utama dalam memberikan pelayanan kesehatan sehingga rumah sakit yang ada baik rumah sakit nasional maupun internasional melakukan penyelenggaraan dan menerapkan sistem keselamatan pasien.

Upaya penyelenggaraan patient safety di rumah sakit untuk meminimalkan risiko kejadian KTD (Kejadian Tidak Diharapkan), mengurangi konflik antara petugas kesehatan dan pasien, mengurangi timbulnya sengketa medis, mengurangi tuntutan dan proses hukum serta mengurangi tuduhan malpraktik yang makin marak terhadap rumah sakit. Dalam hal ini setiap rumah sakit melakukan pembenahan dalam sistem pemberian layanan kesehatan bagi pasien/klien untuk memberikan peningkatan pelayanan kesehatan yang lebih maju dan bermutu.

Pengembangan upaya peningkatan mutu pelayanan pada saat ini mengarah pada patient safety. Dalam World Health Assembly pada tanggal 18 Januari 2002, WHO Executive Board yang terdiri dari 32 wakil dari 191 negara anggota mengeluarkan suatu resolusi yang disponsori oleh pemerintah Inggris, Belgia, Italia dan Jepang untuk membentuk program patient safety (WHO, 2010). 
WHO (World Health Organization) tahun 2004 mengumpulkan angka-angka penelitian rumah sakit di berbagai negara yaitu Amerika, Inggris, Denmark dan Australia ditemukan KTD (Kejadian Tidak Diharapkan) dengan rentang 3,2\% - 16,6\%. Data tersebut menjadi pemicu di berbagai negara untuk melakukan penelitian dan pengembangan sistem keselamatan pasien (Depkes, 2006).

Sehingga dari data tersebut memberikan dasar bahwa keselamatan pasien sangatlah penting. Untuk itu bagi para pemberi layanan kesehatan diharapkan melaksanakan budaya keselamatan bagi pasien/klien.

Menurut Powell (2004) menyatakan bahwa budaya keselamatan merupakan faktor dominan dalam upaya keberhasilan keselamatan dan kunci bagi terwujudnya pelayanan yang bermutu dan aman serta harus menjunjung tinggi nilai dasar yang terdiri dari kedisplinan, ketaatan terhadap standar, prosedur dan protokol, bekerja dalam tim, kejujuran, keterbukaan, dan saling menghargai.

Gerakan keselamatan pasien merupakan organisasi yang dimana bertujuan untuk menghindari kesalahan pada prinsip dalam pengobatan pasien yang harus dipertanggungjawabkan oleh pimpinan pengobatan. Menurut Healy, J. And
Dugdale (2009) dalam masa 10 tahun terakhir yang menjadi perhatian dunia terhadap pentingnya peranan keselamatan pasien meningkat terhadap bagaimana strategi serta cara dan kegiatan untuk menciptakan keselamatan bagi pasien di rumah sakit.

\section{TUJUAN}

Tujuan penulisan ini adalah untuk mengetahui dan memberi informasi tentang peningkatan pelaksanaan keselamatan pasien dalam pelayanan kesehatan di rumah sakit.

\section{METODE}

Penulisan ini menggunakan metode literature review dengan pendekatan jurnal atau artikel, buku dan e-book yang relevan dan akurat serta berfokus pada peningkatan pelaksanaan keselamatan pasien dalam pelayanan kesehatan di rumah sakit. Adapun jurnal atau artikel dan e-book yang digunakan pada literature review adalah jurnal atau artikel dan e-book yang didapatkan dengan menggunakan Google Scholar, Portal Garuda, dan Jurnal Keperawatan Indonesia. 


\section{HASIL}

Berdasarkan hasil pencarian literatur di dapatkan beberapa standar keselamatan pasien dalam pelayanan kesehatan di rumah sakit sebagai berikut:

\section{Hak Pasien}

Pasien dan keluarga pasien mempunyai hak untuk mendapatkan informasi tentang rencana dan hasil pelayanan termasuk kemungkinan terjadinya insiden. Dalam hal ini diperlukan DPJP (Dokter Penanggung Jawab Pelayanan) yang wajib membuat rencana pelayanan dan memberikan penjelasan secara jelas dan benar kepada pasien dan keluarga pasien tentang pengobatan atau prosedur.

\section{Mendidik Pasien dan Keluarga}

Dalam hal ini fasilitas pelayanan harus mendidik pasien dan keluarga tentang kewajiban dan tanggungjawab dalam asuhan pasien. Dalam pendidikan tersebut diharapkan pasien dan keluarga pasien dapat memberikan informasi yang benar, jujur, jelas, dan lengkap; memahami dan menerima konsekuensi pelayanan; mematuhi instruksi dan peraturan; memperlihatkan sikap menghormati dan tenggang rasa, serta memenuhi kewajiban finansial yang disepakati.
3. Keselamatan Pasien dan Kesinambungan Pelayanan

Dalam hal ini terdapat koordinasi pelayanan secara menyeluruh mulai dari pasien masuk, pemeriksaan, diagnosis, perencanaan pelayanan, tindakan pengobatan, rujukan dan saat pasien keluar. Koordinasi tersebut disesuaikan dengan kebutuhan pasien dan kelayakan sumber daya secara berkesinambungan sehingga pada seluruh tahap pelayanan dapat berjalan baik dan lancar serta mencakup peningkatan komunikasi untuk memfasilitasi dukungan keluarga, pelayanan keperawatan, pelayanan sosial, konsultasi dan pelayanan tindak lanjut lainnya.

\section{Pengunaan \\ Metode-Metode \\ Peningkatan Kinerja Dalam \\ Melakukan Evaluasi dan \\ Program Peningkatan}

\section{Keselamatan Pasien}

Setiap fasilitas pelayanan kesehatan harus melakukan proses perancangan atau desain yang baik yang mengacu pada visi, misi, tujuan, kebutuhan pasien, dan petugas pelayanan serta mengumpulkan data kinerja yang diantaranya terkait dengan pelaporan insiden, akreditasi, manajemen risiko, utilisasi, mutu pelayanan dan keuangan. Dalam fasilitas pelayanan tersebut harus 
melakukan evaluasi intensif dengan menggunakan data dan informasi hasil analisis untuk menentukan perubahan sisitem agar kinerja keselamatan pasien terjamin.

\section{Peran Kepemimpinan Dalam Meningkatkan Keselamatan Pasien}

Dalam hal ini pimpinan mendorong dan menjamin implementasi program keselamatan pasien secara terintegrasi dalam tim antar displin untuk berlangsungnya program proaktif dalam mengidentifikasi risiko keselamatan dan meminimalkan insiden serta menumbuhkan komunikasi antar unit dan individu yang berkaitan dengan pengambilah keputusan.

\section{Mendidik Staf Tentang}

\section{Keselamatan Pasien}

Setiap fasilitas pelayanan kesehatan terutama rumah sakit harus memiliki program pendidikan, pelatihan dan orientasi bagi staf baru serta mengintegrasikan topik keselamatan pasien dalam setiap kegiatan in-service training dan memberikan pedoman yang jelas tentang pelaporan insiden.

\section{Komunikasi Sebagai Kunci Bagi} Staf Untuk Mencapai Keselamatan Pasien

Setiap fasilitas pelayanan perlu disediakan anggaran untuk merencanakan dan mendesain proses manajemen untuk memperoleh data dan informasi tentang hal-hal yang terkait dengan keselamatan pasien serta mengidentifikasi masalah dan kendala komunikasi untuk merevisi manajemen informasi.

\section{PEMBAHASAN}

keselamatan pasien adalah hal yang menjadi perhatian bagi rumah sakit dalam memberikan pelayanan kesehatan pada pasien/klien. Pelayanan kesehatan menurut Departemen Kesehatan Republik Indonesia Tahun 2009 yang tertuang dalam Undang-Undang Kesehatan tentang kesehatan adalah setiap upaya yang diselenggarakan sendiri atau secara bersama-sama dalam suatu organisasi untuk memelihara dan meningkatkan kesehatan, memulihkan kesehatan, mencegah penyakit, dan menyembuhkan penyakit baik perorangan, keluarga, kelompok maupun masyarakat.

Adapun beberapa faktor yang mempengaruhi terhadap kualitas 
pelayanan kesehatan dan keselamatan pasien adalah faktor organisasi seperti iklim keselamatan dan moral, faktor lingkungan kerja seperti susunan kepegawaian dan dukungan manajerial, faktor tim seperti kerja tim dan supervisi dan faktor staf. Dalam keselamatan pasien ini, setiap rumah sakit sudah diwajibkan untuk melakukan gerakan keselamatan pasien dan juga PERSI sudah menerbitkan buku tentang pelaksanaan keselamatan pasien di rumah sakit dan dalam waktu mendatang keselamatan pasien termasuk dalam penilaian akreditasi rumah sakit. Pada prinsipnya pelaksanaan keselamatan pasien sesuai dengan standar departemen kesehatan, namun di dalam pelaksanaanya di sesuaikan dengan kemampuan rumah sakit masing-masing sehingga rumah sakit manapun pelaksanaanya hampir sama.

Pelaksanaan keselamatan pasien dalam pelayanan kesehatan di rumah sakit memiliki peningkatan yang dapat dilihat dari perbandingan Peraturan Menteri Kesehatan Republik Indonesia No. 1691 Tahun 2011 dengan Peraturan Menteri Kesehatan Republik Indonesia No. 11 Tahun 2017 yang memberikan pembaharuan dengan menyesuaikan perkembangan fasilitas kebutuhan pelayanan.

\section{PENUTUP}

Keselamatan pasien merupakan suatu sistem dimana rumah sakit membuat asuhan pasien lebih aman, mencegah terjadinya cidera yang disebabkan oleh keselahan akibat melaksanakan suatu tindakan atau tidak mengambil tindakan yang seharusnya diambil.

Dalam hal ini keselamatan pasien menjadi hal yang penting dalam memberikan pelayanan kesehatan bagi pasien/klien. Sehingga diperlukan para tenaga medis yang memberikan pelayanan kesehatan hendaknya memikirkan dan melaksanakan keselamatan pasien.

Pelaksanaan keselamatan pasien saat ini sudah memiliki peningkatan atau kemajuan yang dapat dilihat dari perbandingan Peraturan Menteri Kesehatan Republik Indonesia No. 1691 Tahun 2011 dengan Peraturan Menteri Kesehatan Republik Indonesia No. 11 Tahun 2017 yang memberikan pembaharuan dengan menyesuaikan perkembangan fasilitas kebutuhan pelayanan. 
Untuk itu keselamatan pasien perlu dilakukan secara maksimal oleh para tenaga kesehatan agar pelayanan kesehatan menjadi lebih baik, bermutu dan berkualitas.

\section{REFERENSI}

Al-asaf, A. F. (2013). Mutu Pelayanan Kesehatan: Perspektif Internasional. Jakarta: EGC.

Departemen Kesehatan RI. (2008).

Panduan Nasional Keselamatan Pasien Rumah Sakit (Patient Safety). Jakarta: Depkes RI.

Departemen Kesehatan RI. (2008). Upaya Peningkatan Mutu Pelayanan Rumah Sakit. Jakarta: Depkes RI.

Firawati, Pabuty, A., Putra, A. S. (2012).

Pelaksanaan Program

Keselamatan Pasien di RUSD

Solok. Jurnal Kesehatan Masyarakat, 74-78.

Ida, Wulandari. (2018). Strategi

Peningkatan Kualitas Pelayanan

Rumah Sakit Berdasarkan

Indikator Mutu Keselamatan

Pasien: Studi Pada Rumah Sakit

Umum Hidayaj Boyolali.

Surakarta: FPUM.
Ismainar, Hetty. (2015). Keselamatan Pasien di Rumah Sakit. Yogyakarta: Deepublish.

Kamil, H. (2010). Patient Safety. Idea Nursing Journal, 1-8.

Machmud, R. (2008). Manajemen Mutu Pelayanan Kesehatan. Jurnal Kesehatan Masyarakat, 186-190. Permenkes RI. (2011). Peraturan Menteri Kesehatan Republik Indonesia Nomor 1691/Menkes/Per/VIII/2011

Tentang Keselamatan Pasien Rumah Sakit. Jakarta: Depkes RI. Permenkes RI. (2017). Peraturan Menteri Kesehatan Republik Indonesia Nomor 11 Tahun 2017 Tentang Keselamatan Pasien. Jakarta: Depkes RI.

Simamora, R. H. (2018). Buku Ajar Keselamatan Pasien Melalui Timbang Terima Pasien Berbasis Komunikasi Efektif: SBAR.

Triwibowo, C., Yuliawati, S., Husna, N. A. (2016). Handover Sebagai Upaya Peningkatan Keselamatan Pasien (Patient Safety) di Rumah Sakit. Jurnal Keperawatan Soedirman, 76-79.

Ulumiyah, Nurul H. (2018). Meningkatkan Mutu Pelayanan 
Kesehatan Dengan Penerapan

Upaya Keselamatan Pasien di

Puskesmas. Jurnal Administrasi

Kesehatan Indonesia, 150-154.

Utarini, A., Djasri, H. (2012).

Keselamatan Pasien dan Mutu

Pelayanan Kesehatan. Jurnal

Manajemen Pelayanan

Kesehatan, 159-160.

Wardhani, Viera. (2017). Buku Ajar

Manajemen Keselamatan

Pasien. Malang: UB Press. 